UDC 621.43.038

DOI: 10.37128/2520-6168-2021-4-4

Vol. 115, No 4 / 2021

\title{
DIAGNOSTICS OF DIESEL ENGINE REFRIGERATION ELEMENTS AND WAYS OF INCREASING TECHNICAL AND ECONOMIC INDICATORS
}

\author{
Svetlana Kravets, Assistant \\ Vinnytsia National Agrarian University \\ Кравець Світлана Миколаївна, асистент \\ Вінницький національний аграрний університет
}

The reliability of automotive equipment is its ability to perform constructively laid down functions without additional labor and material costs to maintain an able-bodied condition for a long time. Due to the fact that the quality of automotive equipment is characterized by its reliability and performance, increasing the level of reliability is an urgent task at the present stage of development of the technical operation of agricultural equipment.

In addition, increasing the reliability of automotive vehicles is a promising way to reduce production costs, since the operation of more reliable equipment requires less labor and material costs.

In the restored FS, the stabilization of the initial parameters during operation depends on many technological factors. The main reasons are those that greatly affect the reliability and have a wide range of characteristics under repair conditions.

Changes in the technical condition of diesel engines during operation have a great impact on the indicators of fuel efficiency and toxicity of exhaust gases, with the former accounting for half of the resource consumption in agriculture. In order to achieve the necessary environmental and economic performance indicators of an autotractor diesel engine, its characteristics and fuel supply parameters should be adjusted in accordance with the operation and operating mode of the engine. Such a solution will make it possible to change the required parameters and characteristics, thereby ensuring the required nature of the flow of such fuel supply processes as spraying, mixture formation and combustion in each mode of operation.

For efficient fuel injection into a diesel cylinder, it is necessary to have a significant reserve of fuel pump performance.

Accordingly, a decrease in productivity can lead to a decrease in the amount of cycle feed. Based on the determination of the fuel consumption in the low pressure line of the system, the following tasks can be solved:

- assess the technical condition of the fuel system in operation;

- to optimize the balance of fuel supply in the experimental FS of the accumulating type and thereby reduce the power consumption for the operation of the system.

Key words: automotive equipment, maintenance, fuel system, diagnostics, high pressure fuel pump $(H P F)$, diesel engine.

Table. 1. Fig. 4. Ref. 9.

\section{Formulation of the problem}

The costs of maintaining the operability of auto-tractor and transport vehicles exceed the cost of new ones, reaching $20 \ldots 25 \%$ of the cost of operation, up to $40 \%$ of which falls on maintenance (WFM) and repair (R). In this regard, the task of full and timely satisfaction of the needs of the country's agro-industrial complex in agricultural machinery by increasing the efficiency of rolling stock operation is one of the most important today.

The solution to this problem is ensured not only by the production of agricultural machinery with high reliability and manufacturability by the country's industrial complex, but also by service services that are working to improve the methods of technical operation and reduce the labor intensity of work on their maintenance and repair.

\section{Analysis of recent researches and publications}

Numerous studies carried out by various scientists in the field of technical operation of automotive vehicles indicate that the efficiency of a diesel engine largely depends on the state of the elements of a high pressure line (HPL) of a FS, malfunctions of which lead to a deterioration in the powerful and economic performance of the engine.

\section{Purpose of the study}

To ensure the operability of the injection pump of a diesel engine by improving the diagnosis of plunger pairs. 


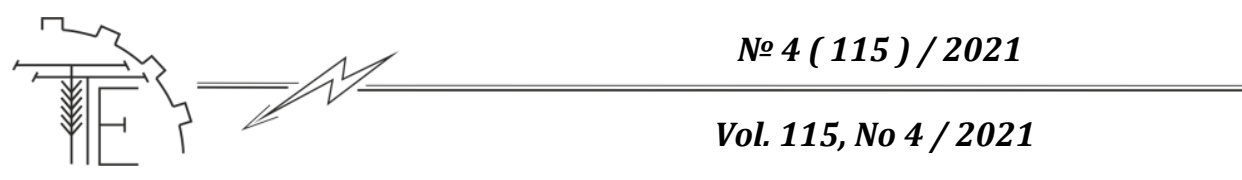

Техніка, енергетика, транспорт АПК

\section{Presentation of the main material}

An injector plays an important role in the power supply system of a diesel engine. The duration, quality and timeliness of fuel supply to the engine cylinder depends on it. The nozzle is designed to inject a certain amount of finely atomized fuel into the combustion chamber.

Each generation of injectors in power supply systems differed from each other, first of all, in the high pressure of fuel injection. If the first diesel injectors were designed for injection pressures of up to $100 \mathrm{MPa}$, then with the development of technology, this indicator on some systems may exceed $200 \mathrm{MPa}$. The pressure increase trend continues as the efficiency and environmental friendliness of diesel engines depends on it. This sophisticated, precision fuel system assembly is required to provide accurate fuel metering. If we consider the injector element by element, then the statistics of the failure of its elements looks something like this: ball valve $-34 \%$, atomizer $-31 \%$, high pressure sealing ring - $23 \%$, the rest - $12 \%$ [1].

The injectors used in fuel equipment differ greatly from each other depending on its type. So, on diesel engines with split-type fuel equipment, such as KAMAZ, YaMZ and ZIL-645, closed-type nozzles with a fixed sprayer and hydraulic needle control are used (Figure 1). The principle of operation is that the fuel entering the nozzle under high pressure from the injection pump passes through the technological channels into the cavity between the nozzle body and the needle, lifts it and is injected into the cylinder. Fuel that has passed through the gap between the needle and the nozzle body is discharged through the channels in the nozzle body and drained into the tank through the drain pipes.

The nozzle is installed in the cylinder head, and the cavity between it and the cylinder head is removed from the ingress of dust and water by means of an O-ring.

The differences between the nozzles of these automotive diesel engines are insignificant and are reduced to design changes, mounting methods in the cylinder head, as well as the number of nozzle openings of the nozzle and the value of the pressure of the nozzle needle rise. So, for a nozzle of an auto-tractor engine of the KAMAZ740 family, 3-5 nozzle openings of the sprayer are characteristic and the working pressure of raising the sprayer needle is from 18.0 to 25.0 MPa. Engines produced by YaMZ have four holes and a pressure of 19.5-20.2 MPa, respectively, the ZIL-645 engine is adjusted for a nozzle needle lift pressure of $18.5+0.5 \mathrm{MPa}$, but has only two holes in the sprayer and the RABA engine - MAN has one hole at a pressure of $18 \mathrm{MPa}$.

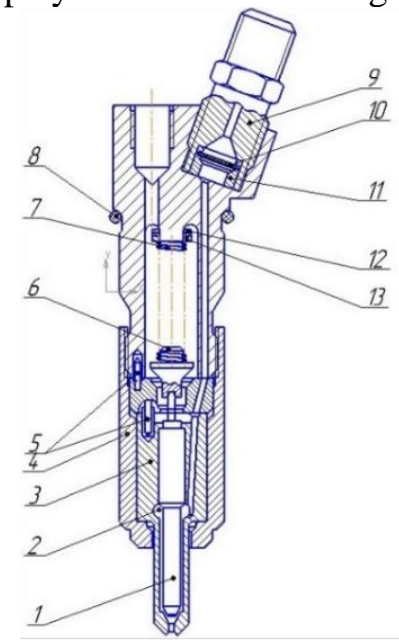

Fig. 1. KAMAZ engine injector: 1 - sprayer; 2-nut; 3 -spacer; 4 -barbell; 5 -housing; 6 - sealing ring; 7 -fitting; 8 -filter; 9 -sleeve;

10 -adjusting washers; 11 -a basic washer; 12 -spring; 13 -spray needle.

Modern nozzles are most often nozzles with pressure control using washers; the spring is located at the bottom of the nozzle, near the sprayer. This solution significantly reduces the size of the nozzle fungus, which simultaneously acts as a spring support, and also reduces the size of the spring, which reduces the mass of the moving parts. At the top, the spring comes into contact with washers, which serve to adjust the opening pressure. Injection occurs when the fuel pressure overcomes the spring force and raises the nozzle needle. For pin nozzles, 11-14 $\mathrm{MPa}$ is set (17.5 $\mathrm{MPa}$ for turbocharged engines), and for perforated nozzles: $15-30 \mathrm{MPa}$.

A very important role in nozzles with pressure control using washers is played by the spacer located between the nozzle body and the spray body. Its main functions are: - connection of the high pressure channel in the nozzle body with the fuel channel in the atomizer; - closing the spring chamber; - in nozzles with perforated sprayers, it is

used to locate the bayonets that determine the position of the sprayer in the nozzle. The surfaces of the spacers are precision-cut and must be perfectly flat, smooth and parallel. The thickness of the spacer in nozzles with "S" size nozzles is $5-9 \mathrm{~mm}$, and its smaller diameter is equal to the diameter of the nozzle flange - $17 \mathrm{~mm}$ ("S" nozzle) or $14.3 \mathrm{~mm}$ ("P" nozzle). The spacer design provides two pins (distance pins) made of steel bar with a diameter of $1.8-3 \mathrm{~mm}$ for precise alignment of the fuel supply line of the nozzle body and the atomizer.

The most common nozzle design is one in which the body is made of steel bar, drawn or turned. Most of the nozzles are produced (according to ISO 2699-1983 and ISO 3539-1975), in three sizes, with nozzle body diameters: 17,21 and $25 \mathrm{~mm}$. 


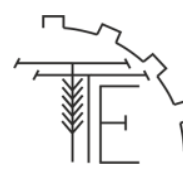

S-size pin-type nozzles usually have a body diameter of $21 \mathrm{~mm}$, while P-type perforated nozzles usually have a 17 or $21 \mathrm{~mm}$ body diameter. In the high pressure channel in the nozzle body there is a slotted filter that retains contamination in the fuel [2].

TA is a highly loaded system of a diesel motor-tractor internal combustion engine. According to the calculations of various TA researchers, a diesel engine of a heavy-duty motor-tractor vehicle under modern operating conditions will spend from 2 to 3 tons of fuel per year, while simultaneously increasing the emission of harmful components into the atmosphere:

- $\mathrm{CO}$ - for $100-150 \mathrm{~kg}$,

- $\mathrm{CH}$ - for $30-50 \mathrm{~kg}$.

The studies carried out have shown that with operational maintenance of a diesel engine, it is possible to obtain a decrease in fuel losses up to $30-40 \%$ and a reduction in the mean time between failures of an internal combustion engine by $15-20 \%$ based on the results of diagnostics. A malfunction of the FS leads to excessive consumption of fuel, loss of starting, traction, economic and environmental properties of the diesel engine. In particular, in the event of a malfunctioning motor-tractor diesel engine of small volume (2.5-3.0 liters) for 10 thousand $\mathrm{km}$ of run it overruns up to $150 \mathrm{~kg}$. fuel, and due to a malfunction of one injector of the same engine - up to $15 \mathrm{~kg}$. With an increase in the engine displacement, the losses grow almost proportionally.

Malfunctions in mechanisms, assemblies of fuel pumps and regulators are manifested in violation of the original adjustments due to wear of parts in the occurrence of extraneous noise, overheating of moving messages and fuel leakage. The main cause of pump failure is wear of parts. At the same time, tensions in fixed landings are weakened and the gap in moving messages increases, the correct mutual arrangement of parts is violated, the surface rigidity of parts changes, foreign deposits in the form of dirt, carbon deposits, etc. accumulate.

When analyzing the main operational malfunctions of parts and assemblies of FS diesel engines, 2 types of malfunctions were identified, as a result of which the FS operability is lost, or the technical and economic performance of the internal combustion engine and agricultural machinery in general deteriorates. The first type of malfunction includes:

- cut of the key of the spline sleeve of the pump drive;

- cut of the spline gear key of the regulator drive;

- breakage of the camshaft;

- breakage of the camshaft bearings;

- breakage of the key and roller of the camshaft of the pump;

- deformation of the high pressure fuel pump pipelines.

As a rule, the listed malfunctions cause a complete failure of the injection pump or a significant deviation in its functional characteristics. They can be caused by long-term operation of the FS with deviations from the manufacturer's specified limit characteristics and operation on contaminated fuel. In case of malfunctions of the second type, the power, environmental friendliness and efficiency of the engine decrease, the volume of fuel supply decreases, its unevenness and duration increase, these include:

- wear of plunger pairs and their seals;

- wear of the discharge valves;

- wear of the plunger leashes;

- wear of the rail clamps;

- wear of the rail teeth;

- deformation of high pressure pipelines;

- deformation of the fuel pump springs;

- failure of the injector;

- wear of the plane of the adjusting bolt of the pusher;

- wear of the roller axis;

- wear of the pusher body;

- roller wear;

- wear of ball bearings and pump casing seats connected to it;

- wear of the camshaft;

- Leakage of seals [3].

Uneven fuel supply to the engine cylinders leads to unstable operation at low speeds, interruptions in the operation of individual cylinders, and significant vibration of the engine block.

Normal operation of FS is characterized by uninterrupted fuel supply and good fuel atomization in the cylinder. Significant effect on the operation of the FS and the quality of the fuel (presence or absence of water and mechanical impurities, viscosity). Monitoring the operation of the FS is reduced to its prevention (flushing the fuel system), testing and regulation. However, diagnostics of FS by the parameters of its 


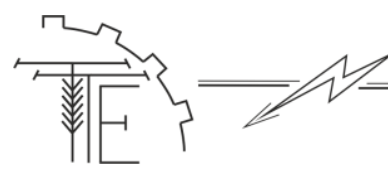

operation will make it possible to reduce the proportion of failures and malfunctions of the diesel engine, as well as significantly reduce the costs of its operation.

For the separated fuel-like equipment used on automotive diesel engines of the KAMAZ family, it is characteristic to diagnose injectors by removing them from the adjustment engine at specialized stands.

The most common method for assessing the technical condition of such a nozzle, used in repair departments and service centers, is to determine the pressure of the beginning of the needle lift, however, in order to fully assess the technical condition of the nozzle, it is also necessary to take into account such parameters as the hydraulic density of the fuel, the quality of the cut and the nature of its cutoff.

This method is constantly being improved. A device for testing and adjusting diesel injectors KI35460 is presented, in which an electronic method is used to determine the quality of fuel atomization by an injector based on an optoelectronic meter and a photo sensor. Removing the nozzle affects the condition of its operation, which leads to the conditional nature of the assessment of the quality of fuel atomization.

Devices are also used to control the pressure of the start of fuel injection without dismantling the nozzle, for example, the Mechanical tester MTA-2 (DD-2120) is shown in Figure 2.

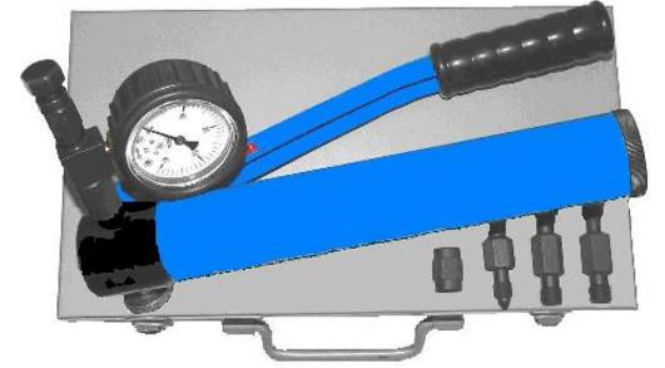

Fig. 2. Mechanical tester MTA-2 (DD-2120)

They are connected in series to the HPD of the section under test. These devices also make it possible to control the maximum pressure developed by the plunger steam. The disadvantage of this control method is the limited number of controlled parameters.

Adjustment of the pressure of raising the nozzle needle is made by installing washers under the nozzle spring or an adjusting screw, depending on the nozzle design.

If necessary, the pressure of the start of fuel injection in the KAMAZ engine injectors is adjusted by changing the total thickness of the regulating washers 10 (Figure 3 a). An increase in the thickness of the washers increases the compression of the spring 12 , and a decrease in their thickness decreases the compression of the spring, which increases or decreases the pressure of the beginning of the stubborn fuel.

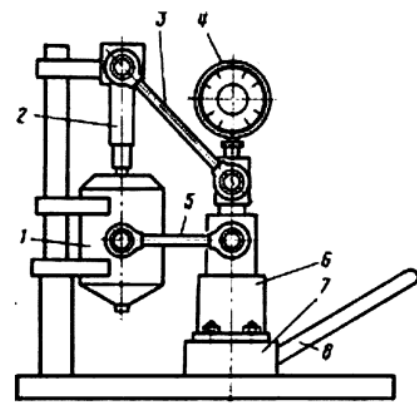

a

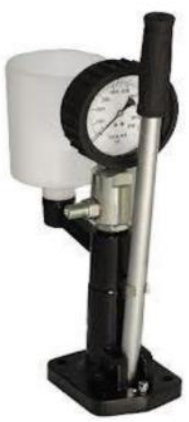

б

Fig. 3. Diagram of the injector test bench and the injector test bench (A1009):

1 -fuel tank, 2 -injector, 3 - high pressure fuel line, 4 -pressure gauge, 5 -fuel supply line, 6 - single section high pressure pump, 7 - base, 8 -drive lever

Changing the thickness of the washers by $0.05 \mathrm{~mm}$ changes the lifting pressure of the nozzle needle by $0.30-0.36 \mathrm{MPa}$.

To check and adjust the injectors, remove them from the engine using a special puller. Tightness, needle start pressure, fuel spray quality and injector capacity are determined on the stand (Figure 3, b). It consists of a single-section high-pressure pump driven by a lever 8 (or electric motor), a fuel tank, a high-pressure fuel line, a pressure gauge, a fuel supply line, and a base.

The quality of the spray is considered good if, when fuel is supplied to the injector $70-80$ by pumping the pump lever per minute, it is injected in a foggy state without drops with a uniform jet cone. The beginning and end of the injection must be clear.

The lower and upper limits of saturation of the composition of the hydrocarbon mixture of rapeseed oil and diesel fuel with an interval of rapid changes in the properties of physicochemical characteristics are determined. The interval of the lower limit starts from 0 and ends with $33 \%$ of the fractions, which determines the saturation with a rapid change in the properties of the mixture. The interval of the upper saturation limit starts from $76 \%$ and ends at $100 \%$, which is complete replacement of the mixture with fuel with the properties of the initial state (diesel fuel). 


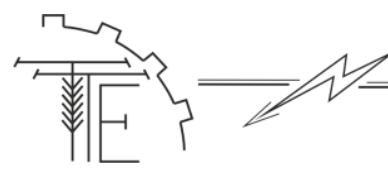

Fuel injection by a new injector is accompanied by a characteristic sharp sound, but if the used injector does not have this sound, it does not mean that the injector is defective.

When coking the nozzle holes, the nozzle is disassembled and the parts are cleaned with a wooden scraper impregnated with diesel oil, then washed in gasoline. The nozzle holes are cleaned with a steel wire with a diameter of 0.25 $\mathrm{mm}$. Leakage of fuel along the spray cone or jamming of the needle indicates a fault in the coupling of the spray gun housing with the needle to be replaced. Also when tightening the spray nut, it must be pre-pressed with emphasis to the conical end until the springs are fully compressed. The moment of an inhaling of a spray of 70-80 N-m. Before installing the nozzle in the cylinder head, as a rule, the seat is cleaned of dirt and check the presence and condition of the sealing washer (ring) [4].

Most injector malfunctions occur as a result of the use of contaminated or low-quality fuel, as well as due to prolonged operation of the engine at low crankshaft speeds at idle. At low speeds, the injection pressure drops sharply, the fuel is sprayed insufficiently, leaks, does not burn completely, the exhaust gases acquire a dark color, which is often accompanied by burning of the nozzle holes of the injectors. The causes of engine cylinder failures and injectors are tested by loosening the injector fitting so that fuel leaks out and does not enter the injector.

If, after switching off the injector, the crankshaft speed decreases, the interruptions in the operation of the cylinders become more noticeable and the smoke of the exhaust gas does not change, the injector of this cylinder should be considered serviceable. If the speed and interruptions do not change, and the smoke of the exhaust gas decreases, it indicates a malfunction of the nozzle, it should be removed and repaired.

One of the reasons for the difficulty of starting the diesel engine is the ingress of air into the power supply system. Air is removed from the fuel system when the engine is not running. To pump the fuel system, unscrew the handle from the cylinder rod of the manual booster pump and move it up and down for a few minutes. In this case, the fuel from the tank is pumped through the coarse and fine filters into the channel of the high-pressure pump, and from there through the bypass valve and pipelines back into the air tank that has entered the system.

With more complex injectors such as pump-injector and Common Rail, computer system diagnostics began to be used. The largest manufacturer of diesel fuel injection systems of this type - Bosch, offers a stand with digital control and electronic continuous measurement system Bosch EPS-815 with CAM-box, which allows qualified testing of EUI and EUP sections, authorized repairs, a complete list of parts and repair technology. currently not provided. It is possible that this situation will be eliminated in the near future.

So far, Delphi is the only manufacturer of pump injectors to provide technology, spare parts and test equipment for repair at the manufacturer's level. EUI and e injection systems Delphi, in cooperation with Hartridge, has developed and offers a program covering the full range of repair and restoration of $\mathrm{A}$ and Ye-1 series pump-injectors [5].

This program includes the recommended test equipment, software, test plans, tools, staff training, diagnostics, parts lists, components themselves. All of the above creates a unique offer for restoration as an alternative to new injectors for diesel engines of cars of the following brands: Volvo, Hyundai, DAF, Land Rover, John Deere. The quality of the refurbished injector pump is not inferior to the original due to the use of the recommended test equipment, tests developed by Delphi engineers, and original components, the quality of which cannot be repeated by any secondary manufacturer.

Thus, AVM2-RS and Bosch EPS-815 are the most high-tech stands with full computer control and automatic test modes with results and evaluation of the performance of EUI and EUP sections at the manufacturer level. This equipment is recommended directly by the manufacturers of pump injectors and pump sections, and they accept the results of authorized work on the specified equipment. The only minus is the cost of different configurations and equipment.

Timely detection of damage and malfunctions of components and units of agricultural machinery leads to a decrease in the intensity of their failures, and as a consequence, to reduce the cost of their operation. Currently, in terms of increasing fuel efficiency and reducing the number of harmful emissions by vehicles, a set of criteria for assessing energy and quality parameters of fuel supply systems of internal combustion engines is introduced, which include: dynamic fuel supply factor, relative fuel spray ratio to average effective capacity stability of fuel spraying, criterion of injection intensification.

Methods of technical diagnostics of diesels, as a rule, are carried out at removal of knot or the unit from the diesel engine for its partial dismantling or adjustment. The most modern method offered is made on the stand of own production, has small consumed power of $2 \mathrm{~kW}$, weight and cost of production, at the same time this stand does not allow to establish a fuel line of the diagnosed TA that negatively influences accuracy of an assessment of a technical condition. The use of this stand in the field is complicated by the fact that it is necessary to protect the diagnosed components from external dust. Also, removing the assembly or unit helps to reduce its service life by $15-20 \%$, even if the part is not repaired. In this regard, the use of modern contactless and non-detachable diagnostic methods based on the analysis of the initial parameters of the diesel engine, which are functionally related to its structural parameters, is expanding. Such diagnostics is a subsystem of information at management 


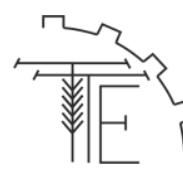

Vol. 115, No 4 / 2021

of a technical condition of autotractor equipment and allows to reveal malfunction of systems and elements of the diesel engine before occurrence of failure without its dismantling.

Currently, leading scientists and other scientific institutions are conducting research aimed at creating new methods of technical diagnostics and diesels, as well as improving the known ones.

To date, the issues of non-demountable methods of technical diagnostics of diesel engines of agricultural machinery have not been studied in depth enough. There are certain developments in the diagnosis of diesels used on tractors and combines. And since the process of fuel supply of automobile, tank and tractor diesels is similar, some methods and means of their technical diagnostics are applicable to agricultural machinery.

Known methods for diagnosing diesel fuel equipment can be divided into groups according to diagnostic parameters and indicators:

- diagnosis according to the characteristics of the FS;

- diagnosis by FS parameters;

- diagnostics on indicators of work of the engine.

Let's consider a possibility of application of the specified methods of technical diagnostics of the fueltaxing equipment of the autotractor diesel engine. The most common method of diagnosis is based on the main indicators of diesel operation. When using this method of diagnosis is carried out on indirect grounds, which can lead to erroneous rulings in more than $50 \%$ of cases, even in the case of diagnosis by an experienced mechanic. Signs of malfunction and autotractor diesel on the performance of the engine are presented in table 1.

Table 1.

Signs of disturbance of normal work of fuel system of the diesel engine and necessary technical influences

\begin{tabular}{|c|c|c|}
\hline $\begin{array}{l}\text { External signs (symptoms) } \\
\text { disorders normal operation }\end{array}$ & $\begin{array}{c}\text { Structural changes } \\
\text { interacting elements }\end{array}$ & $\begin{array}{c}\text { Needed diagnostic, preventive and } \\
\text { repair effects }\end{array}$ \\
\hline 1 & 2 & 3 \\
\hline $\begin{array}{l}\text { Difficult to start the engine. } \\
\text { Unstable work engine }\end{array}$ & Leakage fuel system & $\begin{array}{l}\text { Check for leaks, if necessary } \\
\text { fasten the elements }\end{array}$ \\
\hline $\begin{array}{l}\text { The engine stalls or not develops } \\
\text { sufficient power }\end{array}$ & $\begin{array}{l}\text { Clogging of filters fuel cells } \\
\text { filters }\end{array}$ & Wash or replace filter elements \\
\hline $\begin{array}{l}\text { The engine stalls, no develops } \\
\text { sufficient speed crankshaft }\end{array}$ & Fuel failure pump & $\begin{array}{l}\text { Remove and disassemble the pump, } \\
\text { when need to replace details }\end{array}$ \\
\hline $\begin{array}{l}\text { The engine is running uneven and } \\
\text { does not developpower }\end{array}$ & Clogging of filters nozzles & Check the condition of filters \\
\hline $\begin{array}{l}\text { The engine does not develop } \\
\text { required power, smoky release }\end{array}$ & $\begin{array}{l}\text { Coking blow windows in } \\
\text { cylinder liners }\end{array}$ & Check and clean the windows \\
\hline $\begin{array}{c}\text { Difficult to start and uneven work } \\
\text { engine }\end{array}$ & $\begin{array}{l}\text { Violation of normal work of } \\
\text { nozzles }\end{array}$ & $\begin{array}{c}\text { Remove the injectors and check on the } \\
\text { device }\end{array}$ \\
\hline $\begin{array}{l}\text { Uneven and "hard" engine } \\
\text { operation, release black }\end{array}$ & $\begin{array}{c}\text { Violation of the angle advance } \\
\text { injection fuel }\end{array}$ & $\begin{array}{c}\text { Check and adjust setting the lead angle } \\
\text { injection }\end{array}$ \\
\hline $\begin{array}{l}\text { Uneven work engine with knocks } \\
\text { and smoky release }\end{array}$ & $\begin{array}{c}\text { Violation of regulation rivers } \\
\text { fuel pump }\end{array}$ & $\begin{array}{c}\text { Check and adjust uniformity of supply } \\
\text { fuel in the cylinders }\end{array}$ \\
\hline $\begin{array}{l}\text { The engine is excessive increases } \\
\text { the frequency rotation, there is a } \\
\text { "contribution" }\end{array}$ & Violation of work regulator & Check and adjust regulator or repair \\
\hline $\begin{array}{l}\text { The engine does not develop } \\
\text { capacity, the air cleaner is dark } \\
\text { butter }\end{array}$ & Pollution air cleaner & Wash the filter element, pour oil \\
\hline
\end{tabular}

According to the research of Professor Zhdanivsky NS reduction of internal combustion engine power by $15-20 \%$, which is a consequence of the deterioration of the technical condition of fuel and tax equipment, is not always possible to detect on indirect grounds.

Changes in diesel idling speed are monitored by the controller, but it is not always possible to estimate the speed mode held by the controller under load, which leads to the recommendation to check the number of diesel revolutions under load. Also not very informative diagnostics and diesel on the parameters of smoky exhaust gases and knocks. From the known methods of instrumental control of technical and economic indicators of the high-speed autotractor diesel the most actual:

- brakeless method of Professor NS Zhdanivsky;

- method of determining the power of the diesel by mileage;

- partial method. 


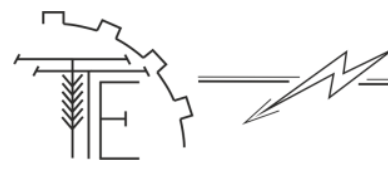

The essence of brakeless and partial methods is to disconnect several cylinders of the running engine, which contributes to the perception of working cylinders not only the load produced by loading devices, but also additional - from mechanical losses occurring in the switched off cylinders. The power of the working cylinder, in this case, is determined by the number of engine revolutions, while controlling the fuel consumption of the cylinders involved. The considered methods allow to estimate the general technical condition of the diesel engine, but the control of a condition of the fuel-taxing equipment is complicated by a set of the factors influencing decrease in powerful and economic indicators of the engine. Thus, fuel consumption in case of loss of compression increases by $4-6 \%$, and when the operating temperature of the engine (coolant temperature) falls below $75^{\circ} \mathrm{C}$ or the formation of soot in the combustion chamber - by $7-12 \%$.

Thus, the performance of the diesel engine depends on the operation of the FS, as well as on other components and units, which makes it difficult to use these indicators as a diagnostic criterion.

The gas-analytical method of diagnosing the fuel-taxable equipment of the D-240 diesel engine consists in an estimation of quality of processes of mixing and combustion based on indicators of the content of soot and $\mathrm{CO} 2$ in the fulfilled gases. Strengthening the standards for the content of harmful substances in the exhaust gases of diesel engines has increased the number of parameters diagnosed by this method, which reduces the informativeness of its diagnostic parameters.

The method of diagnosing diesel FS on the parameters of its work is to assess the quality of regulation and condition of the main elements of FS. Thus, the state of the plunger steam of the pump is monitored by the maximum injection pressure, the amount of fuel supplied and the supply factor. It is known that the process of diesel fuel supply is determined by the operation of the plunger vapor, the wear of which leads to its violation of the increase in the unevenness of the fuel supply, especially in the start modes of the engine.

Deviations of fuel supply by the worn-out plunger steam on a starting mode can reach 70-75\% rather new, and at a nominal speed mode of the diesel the unevenness of fuel supply from 3-5\% increases to 10 $15 \%$. Also, the wear of the plunger vapor helps to delay the start of fuel supply and significantly reduce the duration of its injection at low speeds, which leads to an increase in hourly fuel consumption to $6 \%$ and reduce the effective diesel power to $12 \%$. Progressive wear of the plunger vapor formed during operation has a significant impact on the regularity of fuel supply.

This effect of the wear of the plunger pair on the performance of the diesel engine and the injection parameters of its TA has led to the spread of various methods of monitoring its technical condition.

The most well-known method of monitoring the technical condition of the plunger vapor from the maximum fuel injection pressure, which can be produced in the atmosphere or in a deaf closed chamber. When diagnosing the first method, a maximeter is used. However, this method is not suitable for quantifying the hydraulic density of the plunger vapor due to the small pressure range (up to $50 \mathrm{MPa}$ ), unavoidable fuel leaks due to the needle and low accuracy of the device.

To monitor the technical condition of the plunger steam on the engine use the measurement of the amount of fuel supplied through the injector at a given speed of rotation of the camshaft of the pump. When using this method at low feeds, an additional error is manifested due to fuel leaks along the guide needle of the sprayer. Also, this method is not widely used due to low accuracy and high complexity of measurements.

The next method of controlling the wear of the plunger vapor is the assessment of the supply factor the ratio of the supply of fuel by the plunger vapor through the injector to the fuel supply without the injector. However, this method has the same disadvantages as the previous one, which is a variant of it.

Based on the analysis of methods for monitoring the technical condition of the plunger pair of diesel fuel pumps in operation, it can be concluded that the implemented control methods have low accuracy and performance. At the same time, their use for the purpose of diagnosing TA is not profitable due to the high complexity and the need for a significant amount of assembly and disassembly work.

The characteristics of the fuel-like equipment are also affected by the injection valve of the pump, determined by the wear of its unloading belt. Such wear degrades the quality of the fuel cut-off and increases the residual pressure in the fuel line, which leads to the formation of additional injection fuel with low pressure - injection, which significantly reduces the powerful and economical parameters of the diesel engine.

When diagnosing the pump, it is common to monitor the technical condition of the valve on the shut-off cone using a momentoscope (Figure 4). It is connected to the fitting of the pump shaft, feeding the 1st fuel and rotating at low speed. If the fuel column falls in less than 2 minutes, the discharge valve is considered worn. The disadvantage of this method is that it does not take into account the state of the discharge belt of the discharge valve.

Also an important parameter in the control of the diesel engine FS is the lead and duration of fuel supply, which changes due to wear of the parts of the drive mechanism of the shaft and precision parts of the pump, formed during operation. Changing the angle of advance of fuel injection has a negative effect on the start of the diesel engine, leads to a decrease in power and increase the smoke of the exhaust gases and the noise of the work [6]. 

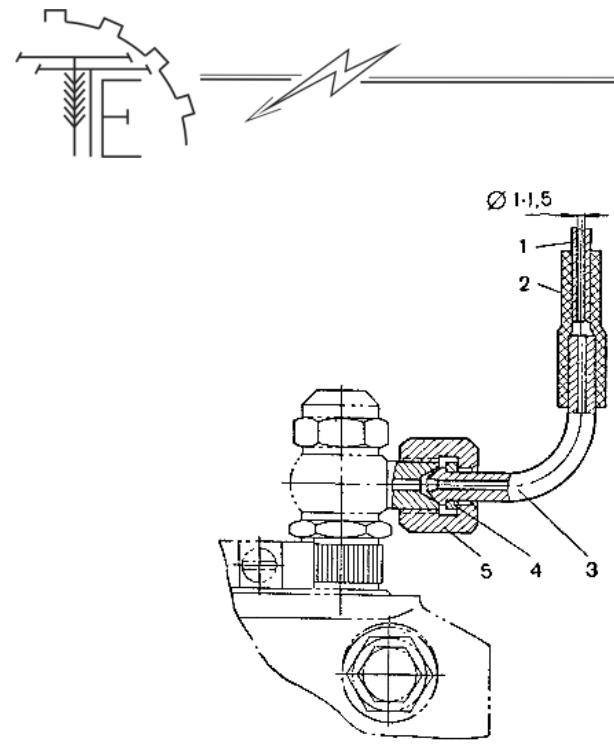

Fig. 4. Momentoscope:

1 -glass tube; 2 -a plastic tube; 3 -a steel tube; 4 -sealing washer; 5 - cap nut

Vol. 115, No 4 / 2021

An essential part of the methods for determining the advance angle and injection duration are used to diagnose tractor diesels. For tractor diesels, during operation, it is recommended to control the angle of advance of fuel entry with a momentoscope. In this case, it is connected to the fitting of the 1st section of the pump and check the coincidence of the adjustment mark of the crankshaftpulley with the mark on the camshaft gear cover, comparing this with the start of the fuel meniscus in the instrument tube.

The use of this method is justified for new plunger pairs and discharge valves, as their wear can lead to significant diagnostic errors. When the pump discharge valve wears (fuel leaks through the shutoff cone or unloading belt), the fuel meniscus in the instrument tube will move ahead, and when the plunger steam wears out (increased plunger-sleeve clearance, seal wear) - with a delay.

Instruments are available to determine the advance and duration of fuel supply, the use of which provides minimal interference in the operation of the FS diesel. In this case, the installation of sensors in the high pressure line (LVD) is typical.

When determining the angle of advance of the fuel supply by the above methods, it is necessary to have access to the flywheel or any mark of the existing diesel pulley for control using a stroboscope, which generally reduces the convenience of their use. To improve the quality of use of these methods, the installation of a pulse sensor corresponding to the position of the piston at the top dead center is considered. In this case, to determine the angle of advance of the fuel injection, the signal from this sensor is compared with the controlled pulse.

The next important indicator of work of FS of the diesel engine is productivity of section of its TNVD. Measurement of fuel consumption at diagnostics can be made on a reference nozzle or with removal of separate nozzles.

However, when working on individual cylinders, it is difficult to achieve stable operation of the engine at low speeds and at rated speed. Also with this method, errors may occur due to the fact that the fuel supply is determined by the performance of the plunger vapor and the technical condition of the injector. Deterioration of the technical condition of the injectors leads to an increase in fuel consumption and smoke of the exhaust gases, a decrease in engine power, a decrease in the stability of operation at low speeds.

Everything that was said earlier indicates the low efficiency of the existing FS maintenance system.

For these reasons, a new approach to determining the technical condition and high pressure of diesels is required. This method can be a control of the technical condition of the tractor diesel by moving the injector needle.

\section{Conclusion}

The analysis of systems and diesels allows us to draw the following conclusions:

1. At present, up to $70 \%$ of the operated agricultural machinery is equipped with fuel equipment with a separate injection system, the diagnosis of which requires dismantling and partial disassembly of its main components and units;

2. Existing methods and means of diagnostics and the diesel engine with the divided injection system differ in a variety of the used diagnostic parameters, insufficient accuracy and rather big labor intensity that limits their application in various conditions;

3. The available FS diagnostic devices do not meet the requirements of operating companies: they are either uninformative or expensive. A promising direction, along with the existing ones, is the movement of the injector needle as a diagnostic parameter associated with changes in fuel pressure and wear of the coupling "plunger-sleeve" of the plunger pair of the pump and determining the performance of the diesel engine FS;

4. It is necessary to give recommendations on the frequency of diagnosis with the selection of a set of diagnostic tools, a set of diagnostic parameters.

\section{References}

1. Adamovsky, M.G., Boris, M.M. (2009). Technical operation and repair of machinery and equipment of the forest complex: A textbook for students of forestry specialties of higher education. Lviv, ORV NLTU of Ukraine. [In Ukrainian].

2. Dubrovsky, V.V., Podvysotsky, O.M. (2008). Investigation of hydraulic characteristics of centrifugal nozzles of cooling towers and ways of their improvement. Probl. common energy. 17. 41-45 [In Ukrainian]. 


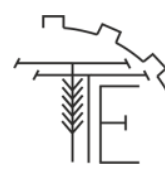

3. Yaremchuk, T.O., Belaya, Ya. Yu., Titova, L.L. (2020). Influence of malfunctions of the fuelsupplying equipment on working capacity of autotractor diesels. Innovative support of organic production in the agro-industrial complex: theses add. International Scientific Conference (Kyiv, August 11-14, 2020). Kiev, 90-91 [In Ukrainian].

4. Kaletnik, H. M. (2019). Perspektyvy pidvyshchennya enerhetychnoyi avtonomiyi pidpryyemstv APK $\mathrm{v}$ ramkakh vykonannya enerhetychnoyi stratehiyi Ukrayiny. Visnyk ahrarnoyi nauky Prychornomor"ya. 4. 90-98 [In Ukrainian].

5. Kaletnik, H.M., Honcharuk, I.V. (2020). Ekonomichni rozrakhunky potentsialu vyrobnytstva vidnovlyuval'noyi bioenerhiyi u formuvanni enerhetychnoyi nezalezhnosti ahropromyslovoho kompleksu. Ekonomika APK. 9. 6-16. DOI: 10.32317/2221-1055.202009006 [In Ukrainian].

6. The practice of diagnosing cars: Textbook. allowance. Ed. Yurchenko AN. M .: NMK PO.[In Ukrainian].

7. Burlaka, S., Kravets, S. (2021). Diagnosis of fuel equipment of diesel engine by removing vybro indicators of fuel supply. Tekhnika, enerhetyka, transport APK. 3 (114). 113123. DOI: 10.37128/2520-6168-2021-3-13 [In Ukrainian].

8. Kishchun, V.A., Borovitsky, I.A. (2016). Modern methods of diagnostics of high pressure fuel pumps of the Common Rail supply system. Bulletin of ZhSTU. 2 (77). 94-101 [In Ukrainian].

9. Kubich, V.I., Korobochka, O.M., Cherneta, O.G. (2018). Questions of operation of machines in legislative and regulatory acts. Cars and tractors: a textbook. Kamenskoe: DSTU, ZNTU. [In Ukrainian].

\section{Список використаних джерел}

[1] Адамовский М. Г., Борис М. М. Техническая эксплуатация и ремонт машин и оборудования лесного комплекса: Учебное пособие для студентов лесотехнических специальностей высших учебных заведений. Львов, ОРВ НЛТУ Украины, 2009. С. 232.

[2] Дубровский В. В., Подвысоцкий О. М. Исследование гидравлических характеристик центробежных форсунок градирен и пути их улучшения. Пробл. общ. энергетики. 2008. № 17. С. 41-45.

[3] Яремчук Т. О., Белая Я. Ю., Титова Л. Л. Влияние неисправностей топливоподающей аппаратуры на работоспособность автотракторных дизелей. Инновационное обеспечение производства органической продукции в АПК: тезисы доп. международной научной конф. (г. Киев, 11-14 августа 2020 г.). Киев, 2020. С. 90-91.

[4] Калетник Г. М. Перспективы повышения энергетической автономии предприятий АПК в рамках выполнения энергетической стратегии Украины. Вестник аграрной науки Причерноморья. 2019. Вып. IV. С. 90-98.

[5] Калетник Г. М., Гончарук И. В. Экономические расчеты потенциала производства возобновляемой биоэнергии в формировании энергонезависимости агропромышленного комплекса. Экономика АРК. 2020. o 9. C. 6-16. DOI: 10.32317/2221-1055.202009006

[6] Практика диагностирования автомобилей: Учебн. пособ. Под ред. Юрченко А.Н. М.: НМК ПО, 1993. С. 216.

[7] Бурлака С., Кравец С. Диагностика топливной аппаратуры дизельного двигателя путём снятия виброиндикаторов подачи топлива. Техника, энергетика, транспорт АПК. 2021. №3 (114). С. 113-123. DOI: 10.37128/2520-6168-2021-3-13

[8] Кищун В. А., Боровицкий И. А. Современные методы диагностики топливных насосов высокого давления системы питания Common Rail. Вестник ЖДТУ. 2016. №2 (77). C. 94-101.

[9] Кубич В. И., Коробочка О. М., Чернета О. Г. Вопросы эксплуатации машин в законодательных и нормативных актах. Автомобили и тракторы: учебное пособие. Каменское: ДГТУ, ЗНТУ, 2018. С. 230.

\section{ДІАГНОСТУВАННЯ ЕЛЕМЕНТІВ ПАЛИВОПОДАЧІ ДИЗЕЛЬНОГО ДВИГУНА ТА ШЛЯХИ ПІДВИЩЕННЯ ТЕХНІКО-ЕКОНОМІЧНИХ ПОКАЗНИКІВ}

Надійність автотракторної техніки - ї̈ здатність виконувати конструктивно-закладені функиії без додаткових трудових $і$ матеріальних витрат для підтримки працездатного стану протягом тривалого часу. В силу того, що якість автотракторної техніки характеризується ї̈ надійністю і пращездатністю, підвищення рівня надійності - актуальне завдання на сучасному етапі розвитку технічної експлуатації сільськогосподарської техніки.

3 іншого боку, підвищення надійності автотракторної техніки - перспективний шлях зниження витрат у виробництві, оскільки експлуатаџія більш надійної техніки вимагає менших трудових і матеріальних витрат.

У відновленій ТА стабілізачія вихідних параметрів при експлуатації залежсть від безлічі технологічних факторів. В якості основних факторів приймаються ті, які максимально впливають на надійність і мають широкий діапазон показників в умовах ремонту.

Зміни технічного стану дизелів у прочесі експлуатащії мають великий вплив на показники паливної економічності та токсичності відпрацьованих газів, причому перие становить половину витрат ресурсів y сільському господарстві. Для досягнення необхідних екологічних та економічних показників роботи автотракторного дизеля, його характеристики та параметри паливоподачі доцільно коригувати 


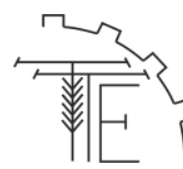

відповідно до експлуатації та рељжиу роботи двигуна. Таке рішення дозволить змінювати необхідні параметри і характеристики, тим самим забезпечувати необхідний характер протікання таких процесів подачі палива як розпорошення, сумішеобразування $i$ згоряння на кожному режимі експлуатації.

Для ефективного впорскування палива в циліндр дизеля необхідно володіти значним запасом продуктивності паливних насосів.

Відповідно, зниження продуктивності може призвести до зменшення величини циилової подачі. Ірунтуючись на визначенні витрат палива в лінії низького тиску системи, можна вирімувати такі завдання:

- оцінити технічний стан паливної системи, щуо знаходиться в експлуатації;

- оптимізувати баланс паливоподачі в дослідної ТА акумулюючого типу і тим самим знизити витрати потужності на функиіонування системи.

Ключові слова: автотракторна техніка, технічне обслуговування, паливна система, діагностування, паливний насос високого тиску (ПНВТ), дизельний двигун.

Табл. 1. Рис. 4. Лim. 9.

\section{ДИАГНОСТИРОВАНИЕ ЭЛЕМЕНТОВ ТОПЛИВОПОДАЧИ ДИЗЕЛЬНОГО ДВИГАТЕЛЯ И ПУТИ ПОВЫШЕНИЯ ТЕХНИКО-ЭКОНОМИЧЕСКИХ ПОКАЗАТЕЛЕЙ}

Надежность автотракторной техники - ее способность выполнять конструктивно-заложенные функции без дополнительных трудовых и материальных затрат для поддержсания работоспособного состояния в течение длительного времени. B силу того, что качество автотракторной техники характеризуется ее надежностью и работоспособностью, повышение уровня надежности - актуальная задача на современном этапе развития технической эксплуатации сельскохозяйственной техники.

С другой стороны, повышение надежности автотракторной техники - перспективный путь снижения затрат в производстве, поскольку эксплуатация более надежной техники требует меньших трудовых и материальных затрат.

В восстановленной ТА стабилизация исходных параметров при эксплуатации зависит от множества технологических факторов. В качестве основных факторов принимаются те, которые максимально влияют на надежность и имеют широкий диапазон показателей в условиях ремонта.

Изменения технического состояния дизелей в процессе эксплуатации имеют большое влияние на показатели топливной экономичности и токсичности отработанных газов, причем первое составляет половину расходов ресурсов в сельском хозяйстве. Для достижения необходимых экологических и экономических показателей работы автотракторного дизеля, его характеристики u параметры топливоподачи целесообразно корректировать в соответствии с эксплуатацией и режимом работы двигателя. Такое решение позволит менять необходимые параметры и характеристики, тем самым обеспечивать необходимый характер протекания таких процессов подачи топлива как распьление, смесеобразование и сгорание на каждом режиме эксплуатации.

Для эффективного впрыска топлива в цилиндр дизеля необходимо обладать значительным запасом производительности топливных насосов.

Соответственно, снижение производительности может привести к уменьшению величинь цикловой подачи. Основываясь на определении расходов топлива в линии низкого давления системы, можно решать следующие задачи:

- оценить техническое состояние топливной системы, находящейся в эксплуатации;

- оптимизировать баланс топливоподачи у опытной ТА аккумулирующего типа и тем самым снизить затраты мощуности на функционирование системы.

Ключевые слова: автотракторная техника, техническое обслуживание, топливная система, диагностирование, топливный насос высокого давления (ПНВТ), дизельный двигатель.

Таб. 1. Рис.4. Лит. 9.

\section{INFORMATION ABOUT THE AUTHOR}

Svitlana Kravets - Assistant of the Department "Technological Processes and Equipment of Processing and Food Production" of Vinnytsia National Agrarian University (3 Sunny Street, Vinnytsia, 21008, Ukraine, email: swkravec2017@gmail.com, https://orcid.org/0000-0001-8296-1929).

Кравець Світлана Миколаївна - асистент кафедри «Технологічних процесів та обладнання переробних і харчових виробництв» Вінницького національного аграрного університету (вул. Сонячна, 3, м. Вінниця, 21008, Україна, e-mail: swkravec2017@gmail.com, https://orcid.org/0000-0001-8296-1929)

Кравець Светлана Николаевна - ассистент кафедры «Технологических процессов и оборудования перерабатывающих и пищевых производств» Винницкого национального аграрного университета (ул. Солнечная, 3, г. Винница, 21008, Украина, e-mail: swkravec2017@gmail.com, https://orcid.org/0000-0001-8296-1929) 